\title{
ESTIMATING PEDESTRIANS’ ROUTE CHOICE PROBABILITY IN UNDERGROUND SPACE BASED ON OD MATRIX AND FLOW COUNT DATA
}

\author{
歩行者交通量に基づく地下空間における歩行者の経路選択確率の推定
}

\section{Zongchao GU* and Toshihiro OSARAGI**}

顧 宗 超, 大佛 俊 泰

\begin{abstract}
Underground spaces connected with railway stations gather a lot of pedestrians. Clarifying pedestrians' movement in underground space is important for flow control and evacuation planning. Based on a pedestrian traffic survey data and estimated OD matrix, this study aims to clarify the pedestrians' route choice probability in underground space. Through the definition of "state" and "transition process", pedestrians' route choice model is constructed according to the utility of routes. Next, Absorbing Markov Process is adopted to solve the trip assignment in the underground pedestrian network and build the functional relation between estimated flow counts and obtained data. Through minimizing the difference between estimated and observed flow counts, unknown variables are calibrated. Finally, the influential spatial motion attributes are examined through linear regression analysis.
\end{abstract}

Keywords : U nderground space, Pedestrian survey data, Route choice probability, Dynamic discrete choice model, Absorbing Markov process

地下空間, 歩行者交通量調査, 経路選択確率, 動的離散選択モデル, 吸収マルコフ過程

\section{Introduction}

Estimating pedestrians' movement and their spatio-temporal distribution in underground space is important for pedestrian flow control and evacuation planning. ${ }^{11}$ Estimating route choice probability is the essential approach for estimating pedestrians' spatio-temporal distribution in underground space.

Pedestrians' spatio-temporal distribution is a kind of time series data which describe pedestrians' spatial positions in a certain area. A numerical analysis approach is proposed to estimate pedestrians' spatio-temporal distribution in underground space (Fig.1). The method of estimating Origin-Destination (OD for short) matrix based on flow count data has been discussed by $\mathrm{Gu}$ and Osaragi ${ }^{2}$. Using obtained OD matrix, this paper aims to estimate pedestrians' route choice probability in the underground pedestrian network. The result of estimation can be used to recreate pedestrians' spatial movement in underground space through simulation analysis so as to clarify pedestrians' spatio-temporal distribution in underground space. Also it can be used as initial data for spatial evaluation for underground pedestrian space.

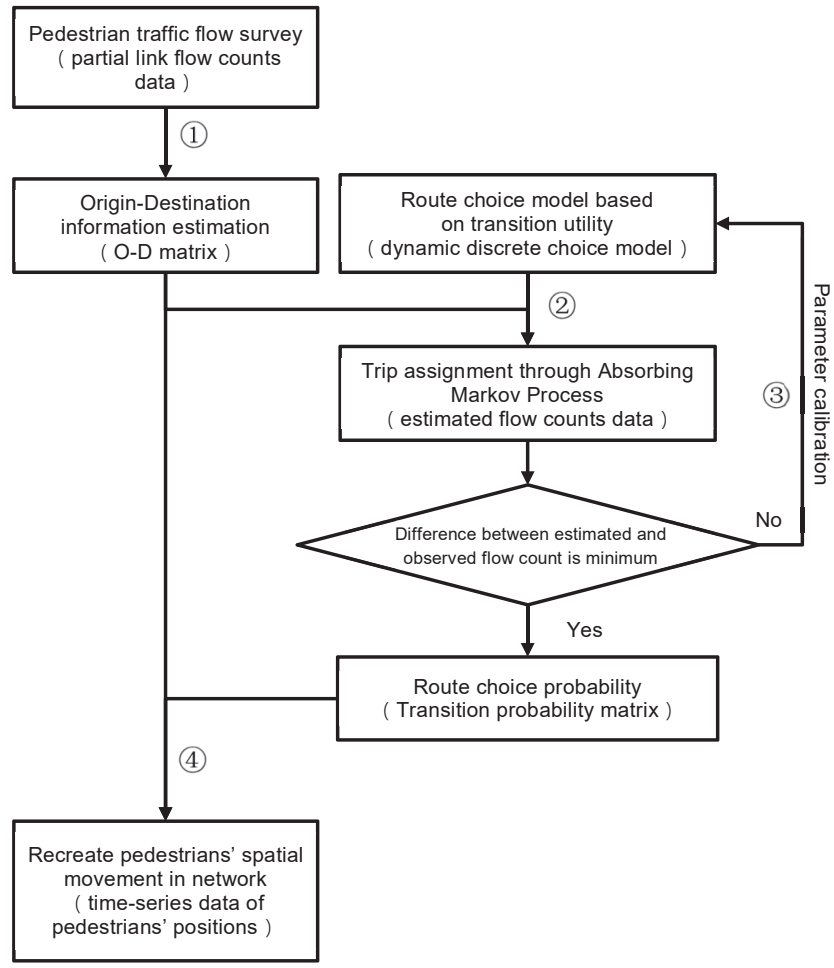

Fig. 1 Framework of spatio-temporal distribution estimation

* Grad. Student, Interdisciplinary Graduate School of Science and Engineering Tokyo Institute of Technology, M. Eng.

東京工業大学大学院総合理工学研究科人間環境システム専攻 修士(工学)

東京工業大学環境 · 社会理工学院 教授 ·博士 (工学) 
Table1 Previous research about pedestrians' route choice behaviors

\begin{tabular}{|c|c|c|c|c|c|c|c|}
\hline \multirow{2}{*}{ Previous studies } & \multirow{2}{*}{$\begin{array}{l}\text { Reference } \\
\text { index }\end{array}$} & \multicolumn{2}{|c|}{ Model category } & \multicolumn{3}{|c|}{ Influential factors } & \multirow{2}{*}{$\begin{array}{l}\text { Viewpoints } \\
\text { (Shortages) }\end{array}$} \\
\hline & & $\begin{array}{c}\text { Path } \\
\text { enumeration }\end{array}$ & $\begin{array}{l}\text { Sequential } \\
\text { process }\end{array}$ & $\begin{array}{c}\text { Spatial } \\
\text { attributes }\end{array}$ & $\begin{array}{l}\text { Environmental } \\
\text { attributes }\end{array}$ & \begin{tabular}{|c|} 
Global \\
attributes
\end{tabular} & \\
\hline Asano et al. (2008) & 3) & O & & O & & & \multirow{2}{*}{$\begin{array}{l}\text { Enumerate a set of feasible paths ("route" in Reference 3)) } \\
\text { between OD pair and consider alternative paths as choice set. } \\
\text { (hard to enumerate all feasible paths in complex networks) }\end{array}$} \\
\hline Bekhor, S. et al. (2006) & 4) & O & & O & & & \\
\hline $\begin{array}{l}\text { Tsukaguchi and Matsuta } \\
(2002)\end{array}$ & 5) & & O & O & - & & $\begin{array}{l}\text { Consider "direction change" and "direction to destination" as } \\
\text { main influential factors at sequential choice model. } \\
\text { (ignore environmental attributes and subsequent route) }\end{array}$ \\
\hline Itoh and Hato (2013) & 6) & & O & O & O & & $\begin{array}{l}\text { Dynamic discrete route choice model considering subsequent } \\
\text { route attributes; Sequential process. } \\
\text { (solve destination choice and route choice at the same time) }\end{array}$ \\
\hline Hill, M. R. （1982） & 7) & & O & $\mathrm{O}$ & & & $\begin{array}{l}\text { The route directness (length and complexity) is the most } \\
\text { common reason to choose a particular route. }\end{array}$ \\
\hline Funahashi (1991) & 8) & & O & O & O & & $\begin{array}{l}\text { "The current movement" and "spatial direction of } \\
\text { origin-destination" affect pedestrians' path choice behaviors } \\
\text { in grid network. }\end{array}$ \\
\hline Takeuchi (1977) & 9) & & & O & O & & \multirow{2}{*}{$\begin{array}{l}\text { Road environment (e.g. width, shops, automobile flow, road } \\
\text { pavement) affects pedestrians' route choice behaviors. } \\
\text { (difficult to apply constructed model to other places) }\end{array}$} \\
\hline Takatsuji and Fukami (1983) & 10) & & & O & O & & \\
\hline Yoshimura et al. (1993) & 11) & & O & $\mathrm{O}$ & $\mathrm{O}$ & & $\begin{array}{l}\text { Statistically examined influential factors (both spatial and } \\
\text { environmental) for route choice in underground space. }\end{array}$ \\
\hline Kawada et al. (2014) & 12) & & O & $\mathrm{O}$ & $\bigcirc$ & & $\begin{array}{l}\text { Weights of influential factors vary according to individual } \\
\text { attributes and trip purpose } \\
\text { (not consider look-ahead behaviors) }\end{array}$ \\
\hline $\begin{array}{l}\text { Bovy, P. H. L. and Stern, E. } \\
(1990)\end{array}$ & 13) & & $\mathrm{O}$ & $\mathrm{O}$ & O & & $\begin{array}{l}\text { Environmental attributes' substantial roles in pedestrians' } \\
\text { route choice depend on trip purposes }\end{array}$ \\
\hline Westerdijk, P. K. (1990) & 15) & O & & $\mathrm{O}$ & $\mathrm{O}$ & $\bigcirc$ & $\begin{array}{l}\text { Route attributes' influences (spatial and environmental) to } \\
\text { route choice are examined according to the correlations with } \\
\text { global preference of routes (global attributes) }\end{array}$ \\
\hline
\end{tabular}

There are various researches about pedestrians' route choice behaviors in the past (Table1). In view of model mechanism the route choice models can be mainly divided into two categories: path enumeration and sequential route choice. In the first category ${ }^{3)}{ }^{4)}$, route choices are defined by the paths which are composed of sequences of links to the destination. Pedestrians are considered to make a choice among the feasible paths at the beginning of the trip. The second category ${ }^{5)}{ }^{6)}$ considers the route choice behaviors as a sequential process of link choice at every intermediate intersection in the trip. Because it is difficult to enumerate all feasible paths in a complex network (especially when the cyclic flow is considered) ${ }^{4}$, route choice behaviors are considered as a sequential process in this study. As pedestrians' OD information was determined in the previous study2), a destination-specific route choice model (comparing with reference 6)) is necessary.

As for the influential factors, spatial motion attributes are generally considered as the main influential factors for route choice. Pedestrians are subconsciously minimizing distance as a primary strategy in route choice. Besides that, the complexity of path is also a common reason for choosing a particular path (Hill, 1982)7). Funahashi (1991)8) points out that "the current move direction" and "spatial direction of origin-destination" will affect pedestrians' route choice behaviors. Spatial location's influence on pedestrians' route choice behaviors in underground space is quantitatively examined by Tsukaguchi and Matsuda (2002)5).

What's more, pedestrians' route choice behaviors are also affected by route environment, e.g. width, shops, automobile flow, road pavement and so on. ${ }^{10}{ }^{11}$ 12) Based on questionnaire survey, it is found that environmental attributes' (e.g. commercial distribution) substantial roles in pedestrians' route choice depend on individual attributes ${ }^{12)}$ and trip purpose ${ }^{12)}$ 13). As pedestrians' individual attributes and trip purpose in underground space are time-varying ${ }^{14)}$, their preferences to routes change according to time. Hence, route choice probability in underground space should be time-dependent. In this study route choice probability at different time intervals will be estimated separately.

Considering route attributes (spatial/environmental) as explanatory variables, most of the models make effort to clarify the influential factors and calibrate factors' weights in pedestrians' route choice. However, it is generally difficult to accurately describe pedestrians' route choice probability by route attributes and estimated model can hardly achieve a good fitness in other place ${ }^{5}$. On the other hand, we can also consider all route attributes as one global variable "utility"15) and directly calibrate the value of global variables. With calibrated route utility it is possible to examine the influence of route attributes (e.g. distance and direction changes) and estimate their weights in route choice through regression analysis. 
Based on a pedestrian traffic survey and estimated OD matrix, this study aims to estimate pedestrians' route choice probability in underground streets. As pedestrians' origin-destination information is obtained, route choice probabilities will be calibrated destination-specifically in this study. Considering route choice behaviors as a sequential process, we adopt a dynamic discrete route choice model to present route choice probabilities based on current and subsequent route utilities. In view of the accuracy of model fitness, transition utilities are treated as unknown parameters and calibrated through minimizing trip assignment results' difference with observation data. Pedestrians' route choice probability and spatial distribution are obtained based on estimated transition utilities. With estimated transition utility, it is also possible to clarify influential factors through linear regression analysis and construct the generalized model. The estimated route choice probability can be used for estimating pedestrians' spatio-temporal distribution data and provide initial data for pedestrians flow simulation.

\section{Data description}

\subsection{Pedestrian traffic survey}

We use the data of the pedestrian traffic survey carried out by Fukuoka city government on 7th (Wednesday) and 11th (Sunday) March 2012. This survey sets 88 observation points in Tenjin underground shopping area (Fig. 2) and counts the number of pedestrians passing by each observation point. The pedestrians' flow counts of two directions have been collected in each hour from 7 am to 8 pm

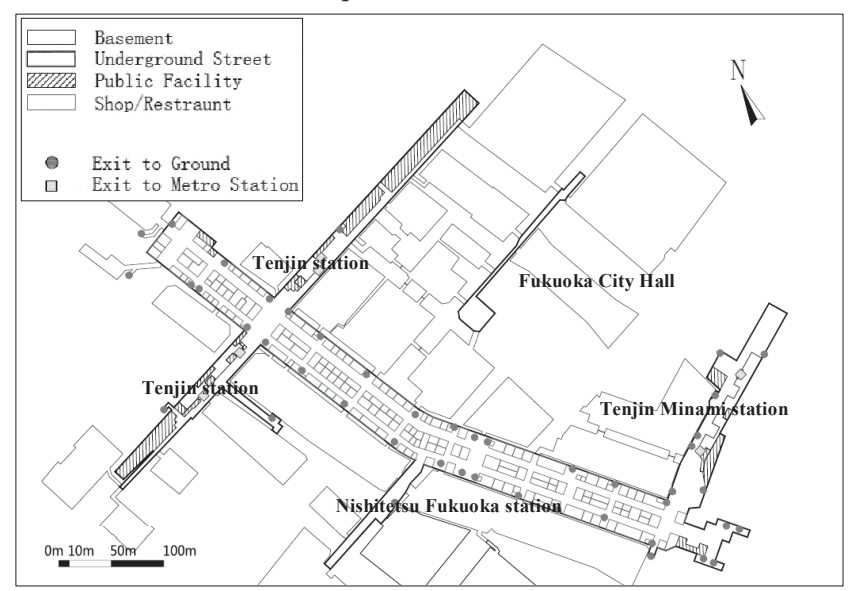

Fig. 2 Map of Tenjin underground shopping area

\subsection{Underground network}

This study selects the underground shopping street as a study area. As shown in Fig. 3, the underground street is graphically represented by a link network. Circles mean the entrances/exits where pedestrians enter into or departure from this area. The dark black links have the flow counts data in two directions, while no data are observed on thin gray links. So pedestrians' movement cannot directly be obtained from the survey data.

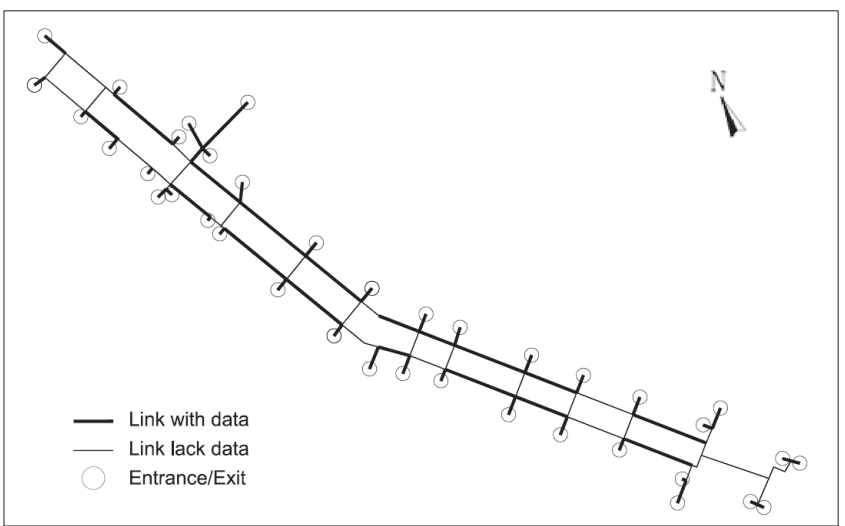

Fig. 3 Pedestrian network in Tenjin underground shopping street

\subsection{OD matrix}

Based on the pedestrian survey data, a set of OD matrix has been obtained through a numerical estimation approach (Entropy maximization approach). The detail of OD estimation is discussed by Gu and Osaragi (2016)2). From OD matrix we can know the trip number between each OD pair in each time interval. However, pedestrian's movement trajectory in the network is not obtained.

The OD estimation method in the previous paper ${ }^{2}$ adopts a specific approach (network simplification approach) to obtain determined link flow count constraints. No route choice models and trip assignment patterns are assumed in previous OD estimation approach. Hence, estimated OD matrixes are independent from pedestrian's route choice models and would not affect the result of choice probability estimation. This issue is discussed in detail in the previous paper ${ }^{2}$.

\section{Pedestrians' route choice behaviors in underground space}

\subsection{Pedestrians' movement in network}

We use "state" and "transition process" to describe pedestrians' movement in underground space. Taking the network shown in Fig. 4 as an example, we define the movement through a link/entrance/exit in a specific direction as the "state" and define the direction from starting node to end node as the state direction. As route choice is generally made at the intersection, this study considers the end node (Node 2 in Fig. 4) in state direction as the spatial location of the state.

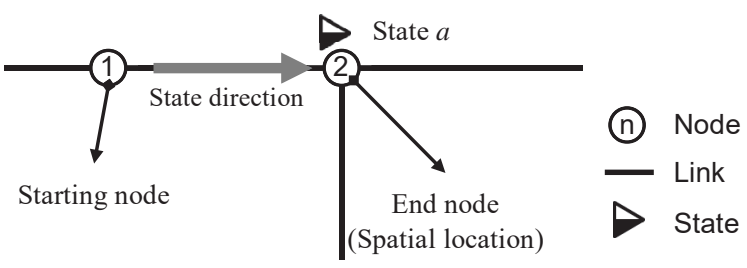

Fig. 4 Definition of state in network 


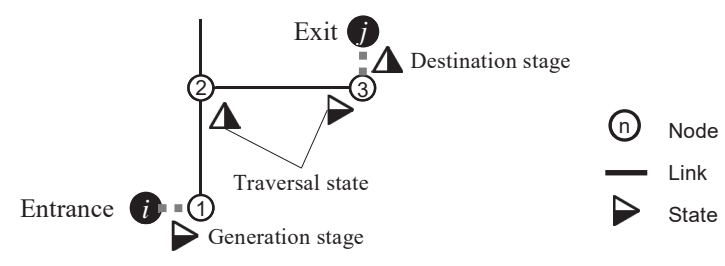

Fig. 5 Category of state in network

As shown in Fig. 5, states in underground pedestrian network can be divided into three categories according to their location in the network;

1) Generation stage: the state of pedestrian entering in the network through an entrance. (Entrance i to node 1 in Fig. 5)

2) Traversal state: the state of pedestrian moving through a link in a specific direction. (Node 1 to node 2 and node 2 to node 3 in Fig. 5)

3) Destination stage: the state of pedestrian departing the network through an exit. (Node 3 to exit j in Fig. 5)

Pedestrians are considered to continuously change their states in the pedestrian network when they are walking to the destination. As shown in Fig. 6, we define the process of transiting from an initial state $a$ to an accessible final state $b$ as the "transition process" from a to b. In this study a transition process contains a single direction, and there is no intermediate state between the initial state and final state.
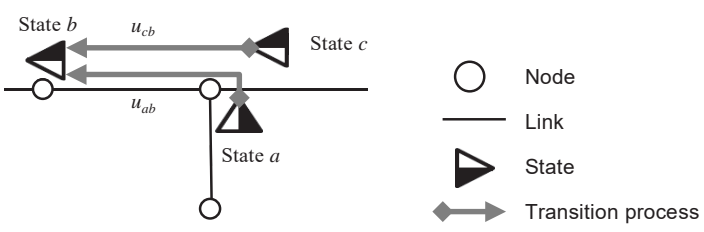

Fig. 6 Definition of transition process

Through the definition of state and transition process, pedestrians' route choice probability in the network can be represented by the transition probability between states. Transition probability is considered to be affected by the utility of routes. ${ }^{19)}{ }^{20)}$ Not like previous research (Itoh and Hato, 2013)6), states are not denoted with utility in this study. We consider utilities of pedestrian choosing a specific state (state b in Fig. 6) from different states (state a and state c in Fig. 6) are not the same. Here we define the utility pedestrian benefits through the transition process by transition utility.

In view of the widths of passages in Tenjin underground street, this study considers pedestrians' route choice will not be affected by flow congestion. Hence, transition utility $u_{a b}$ here is flow-independent value. According to the discussion about influential factors ${ }^{7)}$ 8) 10) 11) 12), the utility of transition process relates the scalar attributes (e. g. distance, environmental attributes) and the vector spatial attributes (e.g. direction change, sign guidance) of transition process.

\subsection{Route choice model}

A dynamic discrete choice model is proposed to describe pedestrians' route choice behaviors in downtown area by Itoh and Hato (2013)6). In existing model pedestrians' destination is not determined, and route choice model is established by solving destination choice problem and route choice problem at the same time. It means that in existing model transition probability between states is the same for all pedestrians. In this study pedestrians' OD information in the underground street is obtained, and it is considered that pedestrians with different destination should have different transition probabilities. Hence, we cannot directly apply existing model ${ }^{6}$ to our case. This study proposes a new model which can separately describe route choice behavior according to pedestrians' destination.

For a pedestrian who destines to destination $\mathrm{j}$ in Fig. 7, the utility of choosing alternative state $b$ at current state $a, U_{a b}^{j}$, is composed of two parts

$$
\mathrm{U}_{\mathrm{ab}}^{\mathrm{j}}=\mathrm{u}_{\mathrm{ab}}+\beta \mathrm{E}_{\mathrm{b}, \mathrm{j}},
$$

where $u_{a b}$ is the utility of transition process from state a to state $b$, and $\mathrm{E}_{\mathrm{b}, \mathrm{j}}$ is the expected utility of subsequent transition processes to the destination stage j. $\beta$ here is discount parameter.

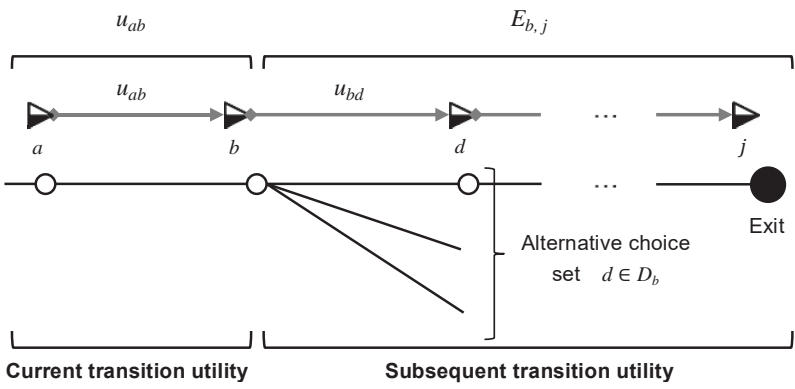

Fig. 7 Route choice utility for pedestrians

As shown in Fig. 7, $E_{b, j}$ is defined by the maximum expected utility of subsequent transition processes till the destination $j$. According to the previous research ${ }^{6} E_{b, j}$ is denoted by the value function of state $b$ in a dynamic programming problem. The value function of state $b$ of the optimal solution is given by

$$
E_{b, j}=V_{b}(u, j)=\max _{d \in D_{b}}\left\{u_{b d}+\beta V_{d}(u, j)\right\}
$$

where $d \in D_{b}$ is a set of alternative states available at state $b . u$ means the set of transition utilities in the network. Value function $V_{b}(u, j)$ stands for the maximum expected utility of subsequent transition processes from state $b$ to destination $j$. The value function $V_{b}(u, j)$ can be obtained by estimating the unique fixed-point of Bellman function in dynamic programming. $\left.{ }^{6}\right)$ As Eq. (2) is represented by a recursive function, $V_{b}(u, j)$ is decided by 
the set of transition utilities $u$ in the network. The route choice utility $U_{a b}^{j}$ gets to be a function which takes the set of transition utilities $u$ as explanatory variables,

$$
\mathrm{U}_{\mathrm{ab}}^{\mathrm{j}}=\mathrm{u}_{\mathrm{ab}}+\beta \mathrm{V}_{\mathrm{b}}(\mathrm{u}, \mathrm{j}) \text {. }
$$

Based on random utility theory the transition probability from state a to state $b$ can be obtained using a logit model,

$$
P_{a b}(u, j)=\frac{\exp \left(u_{a b}+\beta \bigvee_{b}(u, j)\right)}{\sum_{b^{\prime} \in D_{a}} \exp \left(u_{a b^{\prime}}+\beta \bigvee_{b^{\prime}}(u, j)\right)},
$$

where $b^{\prime} \in D_{a}$ is a set of alternative states available at the state $a$. Both of route choice utility $U_{a b}^{j}$ and value function $V_{b}(u, j)$ are destination-specific value. Comparing with the existing model ${ }^{6)}$ transition probability $P_{a b}(u, j)$ in this study is a destination-specific value which is independent from pedestrian's destination choice behavior. Besides that $P_{a b}(u, j)$ is determined by the set of transition utility $u$ in the network.

\section{Parameter calibration}

In the previous chapter, pedestrians' route choice probability is described by transition utility $u_{a b}$. In view of the previous research, this study directly considers transition utility $u_{a b}$ as global variables ${ }^{15}$ ) and aims to estimate pedestrians' route choice probability through calibrating a set of transition utility u which minimizing flow count difference with observation data ${ }^{16) 17)}$. The functional relation between route choice probability and link flow counts can be described by trip assignment model.

\subsection{Trip assignment through Absorbing Markov Process}

As pedestrians' OD information is already obtained, route choice probability determines pedestrians' spatial distribution in the network. Absorbing Markov process is a possible means to solve trip assignment problem. In the previous researches ${ }^{6)}$ 18) 19), absorbing Markov process is used to estimate link flow in the network when route choice probability is obtained. In this study absorbing Markov process is adopted to estimate route choice probability based on OD matrix and observed link flow counts.

As defined in chapter 3, pedestrians' movement through a link are considered as the "state" in Markov process. The processes of transiting between two states correspond to the "state transition" (event) in the Markov process. It is assumed that pedestrians generated from an origin state (generation stage) and repeat changing their states according to the Markov process till they are absorbed by their destination states (destination stage). Based on OD matrix and a set of transition probability, the state flow counts at each traversal state after infinite transition can be calculated by matrix operation. According to the previous research ${ }^{18) 19)}$, in absorbing Markov process the functional relation between route choice probability and state flow counts of pedestrians who destine to destination stage $j$ are given by

$$
x_{j}(u)=T_{j} Q[I-P(u, j)]^{-1}
$$

where $T_{j}=\left[T_{1 j}, T_{2 j}, \ldots, T_{g j}\right]$ is a set of row matrix which represents the trip generation from each entrance, and $\mathrm{g}$ is the number of generation stage. $T_{j}$ is known from obtained OD matrix. $Q$ is a $g-b y-m$ matrix with element value of 0 or 1 which remarks the traversal states' connecting with generation stages. $\mathrm{m}$ is the number of traversal states. I is a unit matrix with $m$-by-m elements. $P(u, j)$ is the $m-b y-m$ matrix representing the transition probability between traversal states. The element of $P(u, j)$ can be obtained by Eq. (4). u means the set of transition utility in the network. The aggregate state flow counts of pedestrians to all destination stages is then,

$$
X(u)=\sum_{j=1}^{n} x_{j}(u)=\sum_{j=1}^{n} T_{j} Q[I-P(u, j)]^{-1},
$$

where $n$ is the number of destination stage. The flow counts of each transition process can be obtained by

$$
C_{a b}(u)=\sum_{j=1}^{n} x_{j}(u) P_{a b}(u, j),
$$

where $C_{a b}$ means flow counts from state $a$ to state $b$.

\subsection{Calibration model}

This study aims to estimate the transition probability (represented by transition utility $\mathrm{u}$ ) which most fits the observed data. As the flow count data is collected at some states (links) in this study, the transition utility $u$ can be calibrated by minimizing the difference between estimated flow counts $X(u)$ and observed state flow counts $\bar{X} .{ }^{16) 17)}$ The objective function to be minimized of this problem is constructed by

$$
F(u)=\sum_{c \in C}\left|\bar{X}_{c}-X_{c}(u)\right|
$$

where $c \in C$ is a set of states(links) with observation data. $\bar{X}_{c}$ means the observed flow count data at state $c . X_{c}(u)$ stands for the flow counts at state $c$ which are estimated by Eq. (6). This problem can be solved by optimization methods provided by matlab optimization toolbox, e.g. "fmincon".

\subsection{Parameter calibration result}

This study considers transition utility $u_{a b}$ as destination-independent variables. As there are 562 transition processes which connect 198 states in pedestrian network, transition utility with 562 unknown variables will be calibrated in Eq. (8). As route choice probability is time-dependent, transition utility $u$ of each time interval has been estimated separately through proposed method. Then, transition probability of each time interval can be estimated by Eq. (4).

The degree to which modeled pedestrians' route choice probability fits reality is evaluated by the difference between estimated state(link) flow counts and observed state(link) flow counts. Fig. 8 shows the fitness of estimated link flow counts based on calibrated transition utility $u$ in all time intervals in a weekday. The relative error is $3.25 \%$, and the coefficient of determination (R-square) is 0.99 . Thus, the fitness of proposed 
route choice estimation approach is satisfying. The difference between estimated and observed flow counts is considered to be caused by the error in OD matrix and observation data.

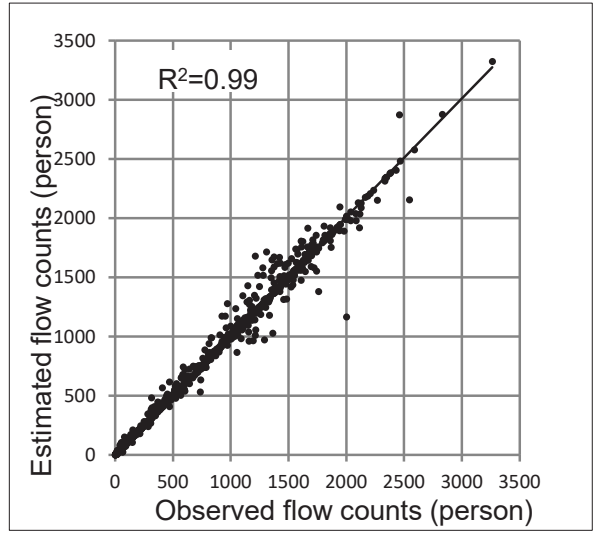

Fig. 8 Fitness between estimated and observed link flow counts

\subsection{Pedestrians' spatial distribution in the underground network}

Applying estimated flow counts in time interval (9:00-10:00), pedestrians' spatial distribution in the underground ground network is shown in Fig. 9. The pedestrian flows at the links without observation data (gray links in Fig. 3) are obtained. As OD matrix is obtained in this study, we can estimate the spatial distribution of the pedestrians flows between each OD pair based on Eq. (5). If the density functions of trip generation velocity at origins are obtained, it is possible to simulate the interaction of the pedestrian flows between each OD pair in the network and evaluate the quality of pedestrian space. The interaction between pedestrian flows will be discussed in the next paper.

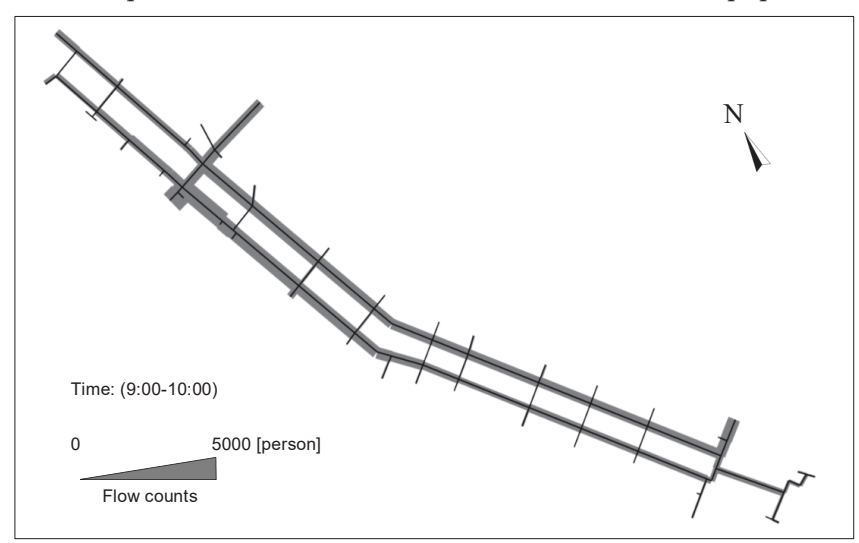

Fig. 9 Pedestrians' spatial distribution in underground network

\subsection{Value function distribution based on estimated transition utility}

Pedestrians' dynamic route choice behavior can be comprehended as a process of pedestrian choosing the alternative states according to their expected utility to the destination. As the value function of destination stage will not affect the transition probability between states, this study denotes the value of value function of destination $j, v_{j}(u, j)$, by 0 . Taking the time interval (9:00-10:00) as an example, state value function for pedestrians who destine to two subway stations are estimated by solving the problem of Eq. (2). The distribution of estimated value function is shown in Fig. 10.

Firstly we want to compare the difference between the existing model ${ }^{6}$ ) and new proposed model. For pedestrians destining to different stations, value function $V_{b}$ of a specific state $b$ is the same in the existing model ${ }^{6}$. However, in Fig. 10 state $b$ has different value function for pedestrians to different stations which indicate route choice is solved destination-specifically. What's more, Fig. 10 shows that value function $V_{b}$ increase as the state getting close to the destination. It means that state with shorter network distance to destination shows higher value function. This distribution tendency corresponds with the facts pedestrians preferring to choose the shorter path. It is confirmed that the value function which estimated through solving the problem of Eq. (2) represents maximum expected subsequent transition utility till destination.

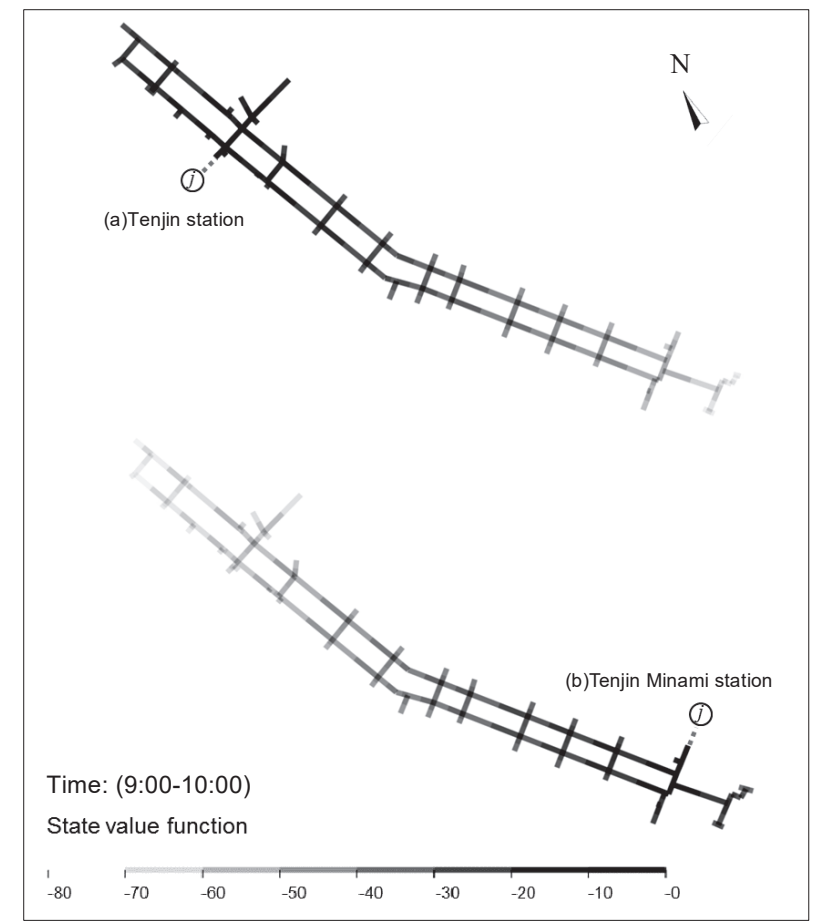

Fig. 10 State value function $\left(\mathrm{V}_{\mathrm{b}}\right)$ distribution in pedestrian network

\section{Regression analysis about influential route attributes}

Considering the accuracy of model, pedestrians' route choice probability in the network is estimated by directly calibrating the utility of transition process between states. To clarify the influential factors for pedestrians' route choice behavior, relationships between the estimated transition utility $u_{a b}$ and spatial motion attributes or environmental attributes are examined through linear regression analysis. The result of analysis can be used to predict the change of pedestrians' spatio-temporary distribution caused by network/environment variation. This paper will take the spatial motion attributes as an example to explain the analysis approach.

5.1. Influential factors for pedestrians' route choice behavior 
With the reference of the previous research5)8113), the following spatial motion attributes (Fig. 11) of transition process are examined;

a) Distance $\left(\boldsymbol{L}_{a b}\right)$ : the length of the link where the final state $\mathrm{b}$ is located

b) Direction change $\left(\boldsymbol{G}_{a b}\right)$ : the cost of direction change; the angle between the direction of initial state a and the direction of final state $b$

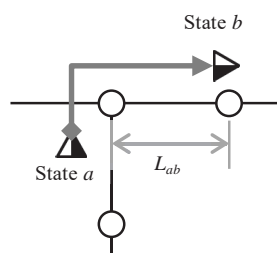

(a)

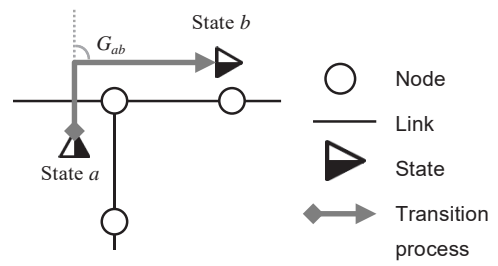

(b)
Fig. 11 Definition of spatial motion attributes

\subsection{Model generalization through regression analysis}

To separately examine spatial motion attributes' influence this study chooses the time interval (9:00-10:00) when most of the shops are closed (except one convenient shop and several cafes) as an example. This study adopts a stepwise method to perform a multilinear regression of the estimated transition utility $u_{a b}$ on the predictive route attributes. The result of regression analysis is shown in Table2. Whether route attributes are accepted as the explanation variables are decided in view of their $\mathrm{p}$-values of $\mathrm{F}$-statistics. As shown in Table2, route attributes are accepted if $p$-values are smaller than 0.05 .

Table2 Estimation results of linear regression analysis

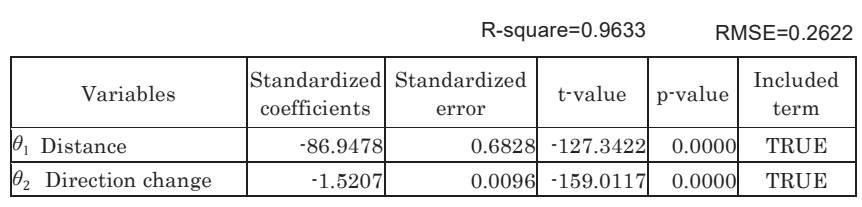

In examined variables, "distance" and "direction change" are two variables significantly related with transition utility. Commercial distribution of "cafe" and "convenient shop" doesn't show significant correlation with transition utility. The transition utility $u_{a b}$ can be described by a regression model;

$$
\mathrm{u}_{\mathrm{ab}}\left(\theta_{1}, \theta_{2}\right)=\theta_{1} \mathrm{~L}_{\mathrm{ab}}+\theta_{2} \mathrm{G}_{\mathrm{ab}},
$$

where $L_{a b}$ is the distance from state a to state $b ; G_{a b}$ stands for the direction change from state a to state $\mathrm{b} ; \theta_{1}$ and $\theta_{2}$ are weighting parameters of spatial motion attributes. These two variables are called spatial parameters in this study.

States flow counts $X(u)$ are estimated through the utility function $u\left(\theta_{1}, \theta_{2}\right)$ described by regression model Eq. (9), and the model fitness with observed state(link) flow counts is shown in
Fig. 12. Thus, although the transition utility function is improved from the viewpoint of generality, the route choice models' accurate descriptive qualities are maintained.

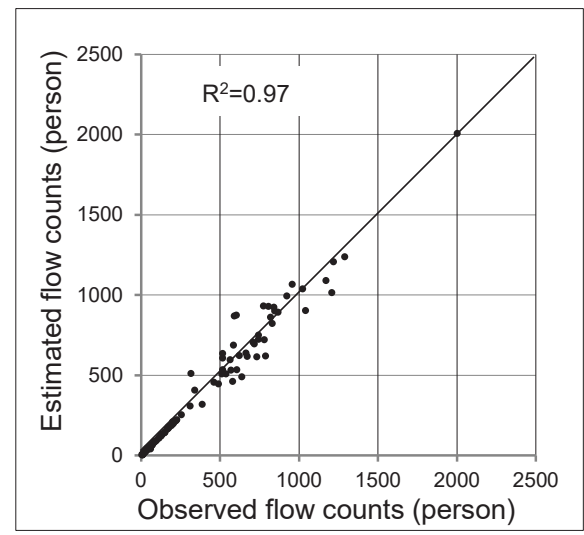

Fig. 12 Fitness of generalized model

\subsection{Spatial parameter and route choice patterns}

Spatial parameters $\theta_{1}$ and $\theta_{2}$ are considered to indicate pedestrians' route choice tendency. In view of the previous research7) 8) 13), their relationship with following route choice patterns has been discussed.

1) Shortest path walking

$\theta_{1}$ is the weighting parameter of transition process's "distance". It is a negative value which indicates the negative correlation between utility and distance of transition process. $\theta_{1}$ is considered to indicates pedestrians' tendency of choosing the path with shorter distance.

To separately examine $\theta_{1}$, here we fix the value of $\theta_{2}$ to the estimated value $\theta_{2}^{*}$ shown in Table2. The degree to which modeled route choice pattern fits the shortest-path pattern is evaluated by

$$
\operatorname{DD}\left(\theta_{1}\right)=\sum_{\mid \epsilon L}\left|\ddot{X}_{\mid}-X_{I}\left(u\left(\theta_{1}, \theta_{2}^{*}\right)\right)\right| .
$$

where $D D$ is defined by the sum of absolute flow counts difference. $\mid \in L$ is the set of states in the network. $\ddot{X}_{\mid}$is the flow counts of state I based on shortest-path assignment, while $X_{1}$ is the state flow counts based on modeled route choice pattern. According to Eq. (8) and Eq. (9), the relation between $\theta_{1}$ and objective function can be represented by;

$$
\mathrm{F}\left(\theta_{1}\right)=\sum_{\mathrm{C} \in \mathrm{C}}\left|\mathrm{X}_{\mathrm{C}}-\mathrm{X}_{\mathrm{C}}\left(\mathrm{u}\left(\theta_{1}, \theta_{2}^{*}\right)\right)\right|
$$

As shown in Fig. 13, as the absolute value of $\theta_{1}$ increases the value of $D D$ decreases. It means that the difference between the modeled trip distribution and the shortest-path pattern distribution decrease. Thus, as the absolute value of $\theta_{1}$ gets larger, the tendency of pedestrians choosing shorter path increases. $F\left(\theta_{1}\right)$ represents the objective function in which $\theta_{2}$ is fixed by the estimated value $\theta_{2}^{*}$. It confirms that the pedestrians do not always take the shortest path in the generalized model. 


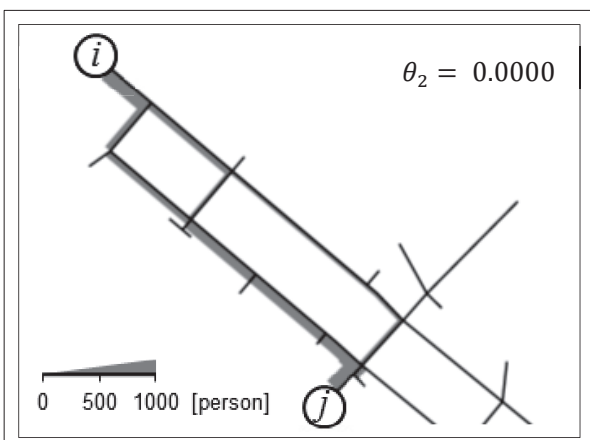

(a)

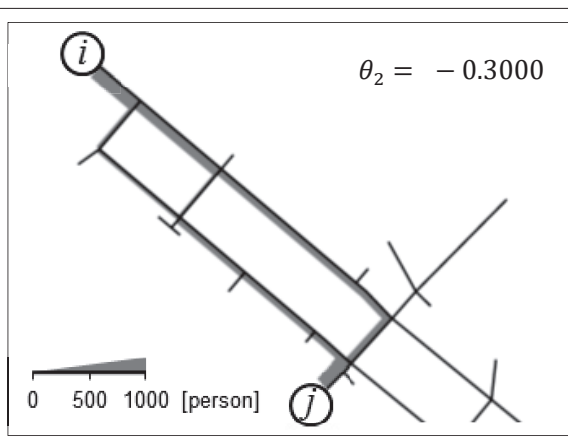

(b)

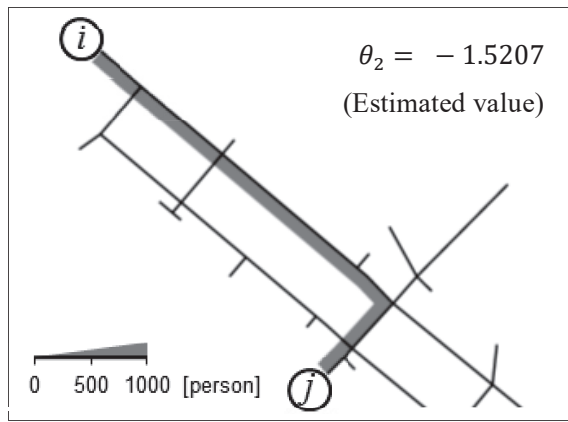

(c)

Fig. 14 Relation between $\theta_{2}$ and simple path walking

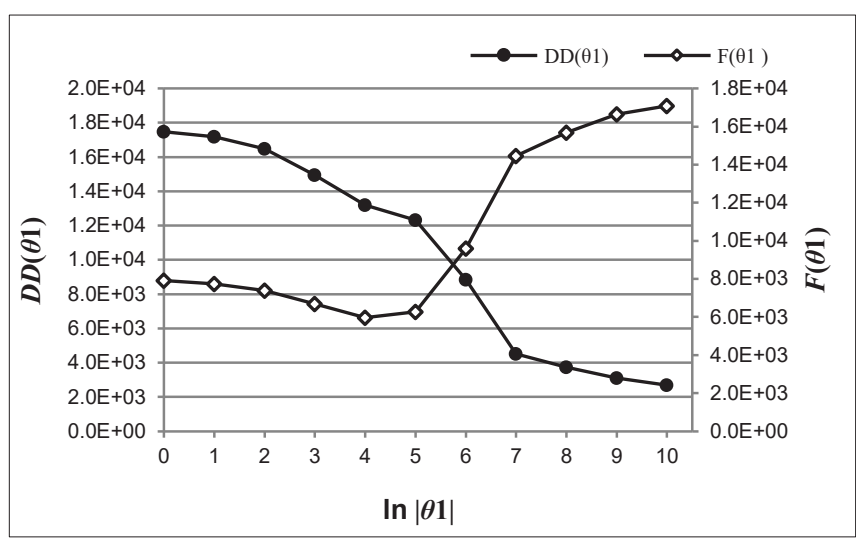

Fig.13 Relation between $\theta_{1}$ and the shortest path walking

\section{2) Simple path walking}

Previous researchers (Hill (1982)7), Funahashi (1991)8) and Tsukaguchi (2002)5) point out that the reason for choosing a particular route is not only the length of the route but also its complexity (in terms of direction changes). The relationship between $\theta_{2}$ and pedestrians' tendency to choose a simple path (path with fewer direction changes) is examined. To examine this relation, this study chooses the OD pair i-j in Fig. 14 as an example. We assign trip number between OD pair by $T_{i j}=1000$ and fix $\theta_{1}$ by the estimated value $\theta_{1}^{*}$. The trip distribution based on $\theta_{2}$ with different value has been obtained. In Fig. 14 there are several equivalent-distances paths between origin and destination. As the absolute value of $\theta_{2}$ increases, the number of pedestrians taking the "simple path" grows.

\section{Conclusions}

Based on the pedestrian flow survey data and estimated OD matrix this paper aims to calibrate pedestrians' route choice probability in underground space so as to estimate pedestrians' spatio-temporal distribution in underground space. Firstly, "state" and "transition process" are defined to represent pedestrians' movement in the underground network. Next, a dynamic discrete choice model is adopted to describe pedestrians' route choice behaviors according to transition utilities. Based on proposed model it is available to estimate state flow counts through trip assignment approach. Through minimizing the difference between estimated flow counts and observation data this study calibrates transition utilities between states and estimates route choice probability in pedestrian network. What's more, spatial motion attributes are examined through linear regression analysis. Methods of estimating pedestrians' spatio-temporal distribution through recreating their spatial motion by simulation approach will be discussed in the future.

\section{Acknowledgements}

The pedestrian traffic survey data used in this paper is supported by Fukuoka City Government.

\section{Reference}

1) Takemoto Kouhei and Nagatani Takashi: Spatio-temporal distribution of escape time in evacuation process, Physica A: Statistical Mechanics and its Applications, Vol. 320, pp. 611-621, 2003

2) Gu Zongchao and Osaragi Toshihiro: Estimating Pedestrians' Movement in Underground Space based on Flow Count Data, Journal of Architecture and Planning, Vol. 81, No. 730, pp. 2625-2634, 2016.12

3) Asano Miho, Kuwahara Masao, Sumalee Agachai, Tanaka Shinji and Chung Edward: Pedestrian simulation considering stochastic route choice and multidirectional flow, Transport Simulation: Beyond Traditional Approaches, EPFL press: pp. 107-123, 2008

4) Bekhor, S., Toledo, T. and Prashker, J.N.: Implementation issues of route choice models in path-based algorithms, Proceedings of the 11th International Conference on Travel Behavior Research, Kyoto, Japan, 2006

5）塚口博司，松田浩一郎：歩行者の経路選択行動分析，木学会論文集， No. $709 / \mathrm{iV}-56$, pp. $117-126,2002.7$

6）伊藤創太, 羽藤英二：動的経路選択モデルを用いた吸収マルコフ連鎖交 通量配分，都市計画論文集，Vol. 48，No. 3，2013.10

7) Hill M. R.: Spatial Structure and Decision-Making of Pedestrian Route Selection through an Urban Environment, Ph.D. Thesis, University Microfilms International, 1982

8）舟橋國男：格子状街路網地区における経路の選択ならびに探索に関する 調査実験, 日本建築学会計画系論文報告集, No. 428, pp. 85-92, 1991. 10.

9）竹内伝史：歩行者の経路選択性向に関する研究, 土木学会論文集, No. 259, pp. 91-101, 1977

10) 高辻秀興, 深海隆恒：住宅地における歩行者の経路選択行動についての 分析, 日本都市計画学会学術研究発表会論文集, No. 18, pp. 199-204, 1983

11）吉村英祐, 柏原士郎, 横田隆司, 渡辺純一：地下街歩行者の経路選択の 要因分析に基づく選択率の予測手法について-梅田地区における場合-, 日本建築学会近畿支部研究報告集，建築計画 (33)，pp. 485-488， 1993.6 
12) Kawada Ko, Yamada Takashi and Kishimoto Tatsuya: Street Choice Logit Model for Visitors in Shopping Districts, behavioral sciences, No.4, pp.154-166, 2014

13) Bovy, P. H. L. and Stern, E.: Route Choice: Wayfinding in Transport Networks. Kluwer Academic Publishers, 1990

14) John Zacharias: Modeling Pedestrian Dynamics in Montreal's Underground City, Journal of Transportation Engineering, American Society of Civil Engineers, Vol. 126, 5, pp. 405-412, 2000

15) Westerdijk, P. K.: Pedestrian and Pedal Cyclist Route Choice Criteria, Working Paper, 1990

16）小山茂, 榛沢芳雄：大手町地区における歩行者交通量の推定に関する研 究, 日本都市計画学会学術研究論文集, pp. 445-450, 1992

17) 櫻井洋子, 腰塚武志：都市の歩行者流動量の推定-豊橋市市街地を対象と して-都市計画論文集，Vo. 147，No. 03， 2012

18) 佐佐木綱: 吸収マルコフ過程による交通量配分理論, 土木学会論文集, No. 121 , pp. 28-32, 1965

19) Akamatsu Takashi: Cyclic flows, Markov process and transportation stochastic assignment, Transportation Research B, Vol. 30, pp. 369-386, 1996

20) Michael G. H. Bell: Alternatives to Dial's logit assignment algorithm, Transportation Research B, Vol. 29, pp. 287-295, 1995

\section{和文要約}

前稿では, 福岡市天神地下街を分析対象として, 歩行者交通量調 查のデータを用いて, 地下街歩行経路における歩行者移動の起点と 終点（OD マトリックス）を推定した。本稿では，推定した OD マト リックスをもとに, 歩行者の時空間分布の推定方法について検討し ている。

まず, ランダム効用理論に基づき, 歩行者の経路選択モデルを構 築し, 歩行者の経路選択確率を記述する方法を構築する。さらに, OD マトリックスと経路選択確率をもとに, 歩行者の地下街歩行経路 における空間移動を推定することで，経路選択時における効用值を 推定する。さらに，この効用值を記述する線形モデルを構築し，経 路選択性向に及ぼす基本的な因子とその性質について議論する。

面的に広がる地下街においては，起点から終点までの移動経路は 多数存在するため,これらをすべて列挙して議論することは難しい。 そこで, 本研究では, 歩行者は交差点ごとに経路選択を行うと仮定 することでモデル化している（逐次的経路選択モデル）。現存する逐 次的経路選択モデルには，意思決定時点の選択肢（交差点に接続す る各リンク）の効用だけを考慮する静的モデルと, 先読みを考慮し た選択後の効用をも考慮する動的モデルに分けられる。地下街にお ける歩行者の経路選択行動においては，動的モデルとすることが自 然と考えられる。本稿では, 動的な逐次的経路選択モデルを構築す ることで, 目的地別に選択確率を求める方法を提案している。

歩行者の経路選択行動には空間定位, 街路環境, 個人属性など非 常に多くの因子が影響すると考えられる。しかし，あまりにも多く の因子を同時に考慮すると, モデルが複雑となり推定が困難となる。 また，各因子の影響の程度は，来街目的や場所性，時間帯などによ り変動するため, ある特定の場所・時間で推定したモデルを，その まま他の地区へ転用することも難しい。そこで，モデル構築の第一 歩として，まず，意思決定時点における各選択肢（経路リンク）の 効用值そのものを未知パラメータとして経路選択時に享受される効 用を構成し，これを用いて選択確率を記述する。ODマトリックスを もとに交通分配法(吸収マルコフ過程)を適用することで，選択肢の
効用值（未知パラメータ）を用いて地下街歩行経路における歩行者 の空間分布を記述する。地下街歩行経路における観測交通量とモデ ルによる推定交通量の差を最小化するパラメータを推定することで, 選択肢効用と選択確率を推定する。

次に，歩行経路選択に影響を及ぼす基本的な因子を抽出すること を目的として，推定した選択肢効用の值を記述する重回帰モデルを 推定する。ここでは, 店舗が及ぼす影響を排除して検討するため, その影響が小さいと考えられる早朝の時間帯のデータを用いて分析 している。その結果, 統計的に有意なふたつの変量（移動距離と方 向変更) が抽出された。推定された重回帰モデルを用いて，簡単な シミュレーション分析を行い, 地下街における歩行者は, 必ずしも 最短経路を選択しておらず，移動方向の変更回数を少なくするよう なシンプルな経路を選択していることを示した。

前稿で推定した OD マリックスと, 本稿で推定した経路選択確率 を用いれば，地下街歩行経路における歩行者の空間移動を再現する ことが可能となり, 歩行者の時空間分布を求めることができる。次 稿では，地下空間における歩行者の時空間分布データを用いて，群 集流動シミュレーション等を実行し, 様々な視点から地下街歩行空 間の評価を試みる予定である。

(2016 年 11 月 7 日原稿受理, 2017 年 5 月 19 日採用決定) 